\title{
Article \\ Exploring the Effects of Different Stubble Tillage Practices and Glyphosate Application Combined with the New Soil Residual Herbicide Cinmethylin against Alopecurus myosuroides Huds. in Winter Wheat
}

\author{
Miriam Hannah Messelhäuser ${ }^{1, *}$, Marcus Saile ${ }^{1}$, Bernd Sievernich ${ }^{2}$ and Roland Gerhards ${ }^{1}$ \\ 1 Department of Weed Science, University of Hohenheim, 70593 Stuttgart, Germany; \\ marcus.saile@uni-hohenheim.de (M.S.); roland.gerhards@uni-hohenheim.de (R.G.) \\ 2 BASF SE, Speyerer Straße 2, 67117 Limburgerhof, Germany; bernd.sievernich@basf.de \\ * Correspondence: miriam.messelhaeuser@uni-hohenheim.de
}

check for updates

Citation: Messelhäuser, M.H.; Saile, M.; Sievernich, B.; Gerhards, R. Exploring the Effects of Different Stubble Tillage Practices and Glyphosate Application Combined with the New Soil Residual Herbicide Cinmethylin against Alopecurus myosuroides Huds. in Winter Wheat. Agronomy 2022, 12, 167. https:// doi.org/10.3390/agronomy12010167 Academic Editor: Md Asaduzzaman Received: 14 December 2021 Accepted: 6 January 2022

Published: 10 January 2022

Publisher's Note: MDPI stays neutral with regard to jurisdictional claims in published maps and institutional affiliations.

Copyright: (C) 2022 by the authors. Licensee MDPI, Basel, Switzerland. This article is an open access article distributed under the terms and conditions of the Creative Commons Attribution (CC BY) license (https:// creativecommons.org/licenses/by/ $4.0 /)$.

\begin{abstract}
Effective control of Alopecurus myosuroides Huds. (blackgrass) solely with a chemical treatment is not guaranteed anymore because populations exhibit resistance to almost all herbicide modes of action. Integrated weed management (IWM) against blackgrass is necessary to maintain high weed control efficacies in winter cereals. Four field experiments were conducted in Southwest Germany from 2018 to 2020 to control $A$. myosuroides with a combination of cultural and chemical methods Stubble treatments, including flat, deep and inversion soil tillage; false seedbed preparation and glyphosate use, were combined with the application of the new pre-emergence herbicide cinmethylin in two rates in winter wheat. Average densities of $A$. myosuroides in the untreated control plots were up to 505 plants $\mathrm{m}^{-2}$. The combination of different stubble management strategies and the pre-emergence herbicide cinmethylin controlled $86-97 \%$ of $A$. myosuroides plants at the low rate and $95-100 \%$ at the high rate until 120 days after sowing. The different stubble tillage practices varied in their efficacy between trials and years. Most effective and consistent were pre-sowing glyphosate application on the stubble and stale seedbed preparation with a disc harrow. Stubble treatments increased winter wheat density in the first year but had no effect on crop density in the second year. Pre-emergence application of cinmethylin did not reduce winter wheat densities. Multiple tactics of weed control, including stubble treatments and pre-emergence application of cinmethylin, provided higher and more consistent control of A. myosuroides. Integration of cultural weed management could prevent the herbicide resistance development.
\end{abstract}

Keywords: blackgrass; herbicide resistance; integrated weed management; soil tillage; glyphosate; mode of action

\section{Introduction}

Since the 1990s, there have been no new modes of action of herbicides. Therefore, the number of available, effective herbicides to combat herbicide-resistant weed populations is strongly limited [1-3]. Alopecurus myosuroides Huds (blackgrass) is a very abundant grass weed in Western European cropping systems [4]. The increasing density of $A$. myosuroides can be attributed to higher proportions of autumn sown crops, such as winter cereals in the crop rotations, reduced tillage practices and a selection of herbicide-resistant populations against all common modes of action [1,5-8].

The seeds of $A$. myosuroides are viable for up to 5 years in soil, but each year approximately $74 \%$ of the seeds in the soil are degraded $[9,10]$. The main germination period of A. myosuroides is in September and October, when most winter annual cereals are sown in Western Europe [9]. Densities of around $100 \mathrm{~A}$. myosuroides plants $\mathrm{m}^{-2}$ cause grain yield losses of $20 \%$ in winter wheat [11]. If not sufficiently controlled, populations can rapidly 
increase to densities of more than 1.000 plants $\mathrm{m}^{-2}$ [12]. To prevent population increase, a control efficacy of minimum $95 \%$ is required [9].

Many A. myosuroides populations in Europe are resistant to post-emergence herbicides, in particular to acetyl CoA carboxylase (ACCase) inhibitors and acetolactate synthase (ALS) inhibitors $[8,13]$. Soil residual herbicides are less affected by resistance since these active ingredients have been used less frequently [14]. Among the most frequently used soil residual herbicides in European winter cereal production are prosulfocarb, flufenacet (HRAC K3/15), pendimethalin (HRAC K1/3) and diflufenican (HRAC F1/12) [14]. Nevertheless, recent studies have confirmed resistance to flufenacet in several populations of $A$. myosuroides $[15,16]$.

Herbicides are the dominant and often the most economically effective tool to control weeds in modern agriculture systems. It is intended to introduce cinmethylin as a new soil residual herbicide to control A. myosuroides and other grass weeds in European winter cereals. The mode of action of cinmethylin was identified in 2018 [17]. It inhibits the fatty acid thioesterases (FAT) in the plastid, which so far has not been identified as an herbicide target. Cinmethylin was traded by the Shell chemical company until 1989 as a pre-emergence herbicide to control grass weeds in rice [18]. Since cinmethylin with its specific new mode of action has not been applied so far in European cropping systems, it is assumed that $A$. myosuroides populations are still sensitive to cinmethylin [19].

However, for sustainable use of a new mode of action such as cinmethylin, integrated weed management (IWM) practices should be applied. During the germination period of $A$. myosuroides, ranging from late summer to early winter, only a small proportion of plants emerge in spring $[9,20]$. This period coincides with the sowing of winter cereals, so some seeds germinate before sowing while others germinate within the crop. Seedlings that emerge prior to seeding can be easily destroyed by tillage or the use of a non-selective herbicide, while those that emerge within the crop require the use of selective herbicides. Consequently, a primary goal of integrated weed management should be to maximize the proportion of pre-sowing seedlings that emerge. To achieve weed control levels of $95 \%$, IWM strategies that combine preventive, non-chemical and chemical measures are needed. Preventive methods like stubble tillage optionally supplemented with non-selective herbicide treatments efficiently control weeds and volunteers in winter cereals [21]. The timing, intensity and frequency can strongly influence the efficacy of stubble treatments [1,22]. Inversion tillage by plough displaces the seeds vertically into deeper soil layers of up to $30 \mathrm{~cm}[5,23]$. Weed control efficacies of up to $69 \%$ can be achieved by lethal germination [1]. Shallow tillage to a depth of maximum $5 \mathrm{~cm}$ was very effective against annual grass weeds including $A$. myosuroides. Seeds with no or a short period of primary dormancy were induced to germinate shortly after tillage. Emerged seedlings could then be removed by seedbed preparation $[24,25]$.

The use of IWM practices has the potential to lead to reduced reliance on herbicides and reduced selection for herbicide resistance [1,5].

The objective of this study was to test the efficacy of the new soil residual herbicide cinmethylin against $A$. myosuroides and the crop response at different locations over two years in winter wheat combined with different stubble treatments. The main hypotheses were that (i) both application rates of cinmethylin provide control efficacies of more than $80 \%$ against $A$. myosuroides until BBCH 30 in winter wheat, (ii) the combination of $375 \mathrm{~g}$ a.i. cinmethylin with different stubble management strategies achieves similar control efficacies to the application of $495 \mathrm{~g}$ a.i. cinmethylin and (iii) pre-emergence application of cinmethylin in combination with a mechanical stubble treatment achieve similar control efficacy of $A$. myosuroides as a sequence with a pre-sowing glyphosate treatment in winter wheat. Further, it was hypothesized that (iv) cinmethylin shows high selectivity and does not reduce winter wheat grain yield. 


\section{Materials and Methods}

\subsection{Experimental Sites}

Four field experiments were conducted in winter wheat in Southwestern Germany over two seasons from October 2018 to August 2020. The four field experiments were located on a conventional farm site in Hirrlingen. Two field experiments were conducted from September 2018 to August 2019 at Binsen $\left(48.2522^{\circ} \mathrm{N}, 8.5315^{\circ} \mathrm{E}\right)$ and $\operatorname{Risp}\left(48.2506^{\circ} \mathrm{N}\right.$, $8.5348^{\circ}$ E) and from September 2019 to August 2020 at Sieben Jauchert $\left(48.2525^{\circ} \mathrm{N}\right.$, $\left.8.5342^{\circ} \mathrm{E}\right)$ and B. Kreuz $\left(48.2526^{\circ} \mathrm{N}, 8.5356^{\circ} \mathrm{E}\right)$. Average monthly temperatures were approximately $2{ }^{\circ} \mathrm{C}$ higher than the long-term average in both years (Table 1). Precipitation in autumn 2018 and 2019 was reduced; additionally, the annual temperature was exceeded by $3{ }^{\circ} \mathrm{C}$ (Table 1$)$. The soil properties of the four experimental sites are shown in Table 2 .

Table 1. Mean temperature and precipitation for the region of Hirrlingen, Baden-Württemberg from September 2018 to August 2020. Long-term means for temperature and precipitation were assessed over the period from 1911 to 2010 [26].

\begin{tabular}{|c|c|c|c|c|c|c|c|c|}
\hline & \multicolumn{4}{|c|}{ Mean Temperature $\left({ }^{\circ} \mathrm{C}\right)$} & \multicolumn{4}{|c|}{ Mean Precipitation (mm) } \\
\hline & 2018 & 2019 & 2020 & Long-Term Average & 2018 & 2019 & 2020 & Long-Term Average \\
\hline Jan & & 0.3 & 3.6 & 0.1 & & 46.6 & 13.2 & 45.0 \\
\hline Feb & & 5.3 & 6.1 & 0.9 & & 18.0 & 89.5 & 42.0 \\
\hline March & & 7.5 & 6.5 & 4.5 & & 40.6 & 40.6 & 56.0 \\
\hline April & & 10.3 & 13.0 & 8.1 & & 31.4 & 6.1 & 64.0 \\
\hline May & & 11.5 & 13.7 & 12.7 & & 116.4 & 45.2 & 104.0 \\
\hline June & & 20.1 & 17.0 & 15.8 & & 75.9 & 96.1 & 96.0 \\
\hline July & & 20.4 & 20.1 & 17.9 & & 85.3 & 35.3 & 101.0 \\
\hline Aug & & 19.6 & 20.5 & 17.4 & & 79.7 & 106.6 & 80.0 \\
\hline Sep & 16.7 & 15.4 & & 13.4 & 20.6 & 36.5 & & 66.0 \\
\hline Oct & 11.8 & 12.1 & & 9.3 & 24.5 & 62.1 & & 68.0 \\
\hline Nov & 5.8 & 5.2 & & 4.0 & 15.4 & 36.3 & & 56.0 \\
\hline Dec & 3.6 & 4.0 & & 1.2 & 55.4 & 37.4 & & 61.0 \\
\hline
\end{tabular}

Table 2. Soil properties of the four experimental locations.

\begin{tabular}{|c|c|c|c|c|c|}
\hline Location & $\begin{array}{l}\text { Corg }_{\text {org }} \\
\% \text { in DM }\end{array}$ & 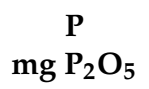 & $\begin{array}{c}\text { Clay } \\
\%\end{array}$ & $\begin{array}{c}\text { Sand } \\
\%\end{array}$ & $\begin{array}{c}\text { Silt } \\
\%\end{array}$ \\
\hline Risp & 1.94 & 45.36 & 27 & 4.2 & 68.7 \\
\hline Binsen & 1.58 & 13.93 & 23.8 & 3.7 & 72.5 \\
\hline B. Kreuz & 1.95 & 13.10 & 31.7 & 3.3 & 64.9 \\
\hline Sieben Jauchert & 1.67 & 10.42 & 23.4 & 3.7 & 72.9 \\
\hline
\end{tabular}

\subsection{Experimental Design}

Each experiment was set up as a two-factorial split-plot design with three repetitions. The plot size of all experiments was $36 \mathrm{~m}^{2}$, while each plot measured $3 \mathrm{~m}$ in width and $12 \mathrm{~m}$ in length. The first factor was the stubble management strategy in the period between the harvest of the previous crop and the seeding of winter wheat, containing nine (Binsen, Risp) and ten (B. Kreuz, Sieben Jauchert) treatments (Table 3). In 2018, one treatment remained unsprayed in combination with no soil tillage (CON), and one treatment remained untilled in combination with the corresponding amount of cinmethylin (HERB). In 2019, these two stubble management strategies (CON; HERB) were merged together in combination with the corresponding amount of cinmethylin (No-till + HERB). The second factor was the herbicide treatment, including a pre-emergence application of LUXINUM ${ }^{\circledR}\left(495 \mathrm{~g}\right.$ a.i. $1^{-1}$ cinmethylin, BASF SE, Germany) in winter wheat with the full recommended field rate of $0.661 \mathrm{ha}^{-1}$ (495 $\mathrm{g}$ a.i. $\left.\mathrm{ha}^{-1}\right)$ and a reduced application rate of $0.51 \mathrm{ha}^{-1}\left(375 \mathrm{~g} \mathrm{a.i.} \mathrm{ha}^{-1}\right)$. In 2019 , the rate of $0 \mathrm{~g}$ a.i. ha ${ }^{-1}$ cinmethylin was added as a third application rate. The application dates were adapted to the individual years. Pre-emergence herbicide cinmethylin 
was applied 5 days after sowing (DAS) in BBCH 10-11 of the crops with a field sprayer (Rau OHG Machinenfabrik, D2, 12 m, Kirchheim, Germany). Seedbed preparation in all treatments was performed by a rotary hoe. Seedbed quality differed between the years according to the weather conditions in autumn. In 2018, the seedbed was extremely rough with usable field capacity $<30 \%$ at the time of herbicide application, and afterwards soil moisture was increased by sufficient rainfall. Because of dry soil conditions at the time of winter wheat sowing in $2018,5 \mathrm{~mm}$ water was added with a boom sprayer directly after pre-emergence herbicide application. In spring, broadleaved weed species were controlled in all plots with Biathlon $4 \mathrm{D}$ (714 g a.i. $\mathrm{kg}^{-1}$ tritosulfuron, $54 \mathrm{~g}$ a.i. $\mathrm{kg}^{-1}$ florasulam, BASF SE, 67056 Ludwigshafen, Germany).

Table 3. Conducted stubble treatments and doses of herbicide application.

\begin{tabular}{|c|c|c|c|c|c|c|}
\hline & \multirow[b]{2}{*}{ Stubble Treatment } & \multirow[b]{2}{*}{$\begin{array}{c}\text { Time of Soil Tillage } \\
\text { (DAH = Days after } \\
\text { Harvest) }\end{array}$} & \multicolumn{2}{|c|}{$2018 / 2019$} & \multicolumn{2}{|c|}{$2019 / 2020$} \\
\hline & & & Binsen & Risp & B. Kreuz & $\begin{array}{c}\text { Sieben } \\
\text { Jauchert }\end{array}$ \\
\hline & & & \multicolumn{2}{|c|}{$\begin{array}{l}\text { 375; } 495 \mathrm{~g} \text { a.i. ha } \\
\text { cinmethylin }\end{array}$} & \multicolumn{2}{|c|}{$\begin{array}{c}\text { 0; } 375 ; 495 \text { g a.i. ha }{ }^{-1} \\
\text { cinmethylin }\end{array}$} \\
\hline $\mathrm{CON}$ & Weed fallow without weed management & - & $\mathrm{x}$ & $\mathrm{x}$ & - & - \\
\hline HERB & Only cinmethylin application without soil tillage & - & $x$ & $x$ & - & - \\
\hline No-till + HERB & No soil tillage with chemical weed management & - & - & - & $\mathrm{x}$ & $\mathrm{x}$ \\
\hline FST & Flat soil tillage with rotary harrow $(5 \mathrm{~cm})$ & $14,35,50$ & $\mathrm{x}$ & $\mathrm{x}$ & $\mathrm{x}$ & $\mathrm{x}$ \\
\hline DST & Deep soil tillage with wing share cultivator $(15-16 \mathrm{~cm})$ & $14,35,50$ & $\mathrm{x}$ & $\hat{x}$ & $\hat{x}$ & $\hat{x}$ \\
\hline PL & Turning soil tillage with plough $(25 \mathrm{~cm})$ & 14 & $x$ & $\mathrm{x}$ & $\mathrm{x}$ & $x$ \\
\hline 1x Gly & Single glyphosate treatment $\left(41 \mathrm{ha}^{-1}\right)$ & 35 & $\mathrm{x}$ & $x$ & $\mathrm{x}$ & $\mathrm{x}$ \\
\hline 2x Gly & Dual glyphosate treatment $\left(41 \mathrm{ha}^{-1}\right)$ & 14,50 & $\mathrm{x}$ & $\mathrm{x}$ & $\mathrm{x}$ & $\mathrm{x}$ \\
\hline $\mathrm{SH}$ & Single time straw harrow $(0.5-1 \mathrm{~cm})$ & 14 & $x$ & $\mathrm{x}$ & $x$ & $x$ \\
\hline $\mathrm{DH}$ & Disc harrow $(7-8 \mathrm{~cm})$ & $14,35,50$ & $\mathrm{x}$ & $\mathrm{x}$ & $\mathrm{x}$ & $\mathrm{x}$ \\
\hline $\mathrm{FSB}+\mathrm{m}$ & False seedbed (flat soil tillage) + rotary harrow & 14,70 & - & - & $x$ & $\mathrm{x}$ \\
\hline FSB + Gly & False seedbed (flat soil tillage) + single glyphosate & 14,70 & - & - & $x$ & $x$ \\
\hline
\end{tabular}

\subsection{Data Collection}

To reduce possible border effects, all measurements were performed only in the 10 center rows of each plot. Density of $A$. myosuroides was determined 56 and 120 days after sowing (DAS). The first date represents the end of the growing season in the year of sowing and the second date corresponds to the end of tillering of winter wheat. Winter wheat density was measured 120 DAS. Within each plot, A. myosuroides and winter wheat plants were counted within a frame of $1 / 10 \mathrm{~m}^{2}$ at four randomly chosen spots. Grain yield $\left(\mathrm{Mg} \mathrm{ha}^{-1}\right)$ was measured by harvesting the center of each plot at a size of $1.5 \mathrm{~m} \times 12 \mathrm{~m}$ to exclude margin effects. Harvest was performed by a plot harvester (Wintersteiger, Elite 3, 4910 Ried im Innkreis, Austria). Because of a hail event in 2019, harvest of the grain yield could only be performed at experimental sites B. Kreuz and Sieben Jauchert. Grain weights were transformed to a homogenous water content of $14 \%$.

\subsection{Statistical Analysis}

The data were analyzed with the statistical software R Studio (Version 3.6.2, RStudio Team, Boston, MA, USA). A linear mixed model was used to evaluate the response of weed density (plants $\mathrm{m}^{-2}$ ), winter wheat density (plants $\mathrm{m}^{-2}$ ) and winter wheat grain yield $\left(\mathrm{Mg} \mathrm{ha}^{-1}\right)$ to the examined factors (stubble management strategy and herbicide treatment) and interactions in the field experiments. Prior to the analysis, the data were visually checked for variance homogeneity and normal distribution of residuals. Results were square root transformed to homogenize variances and to normalize the distribution. In the results section, back transformed means are shown. An analysis of variance (ANOVA) was performed at $p \leq 0.05$. Stubble treatment and weed control method and all interactions between these variables were considered fixed effects. Multiple mean comparison tests were performed using Tukey's HSD test at a significance level of $\alpha \leq 0.05$. 


\section{Results}

\subsection{A. myosuroides Densities 56 and 120 DAS}

At the experimental site Binsen, no significant differences in A. myosuroides density 56 days after seeding (DAS) could be detected. On average, 53 A. myosuroides plants $\mathrm{m}^{-2}$ were measured in the untreated control plots (CON). In spring, 120 DAS, infestation rates of A. myosuroides showed a significant interaction between the stubble management strategies and the two herbicide rates. Densities varied in the CON of up to 505 plants $\mathrm{m}^{-2}$ at Binsen (Table 4).

Table 4. A. myosuroides density (plants $\mathrm{m}^{-2}$ ) 56 DAS and 120 DAS at Binsen. Levels of significance are shown behind the result for each date separately. Means with the same letter are not significantly different according to HSD test at $p \leq 0.05$. Levels of significance are shown behind the result for each date separately.

\begin{tabular}{ccc}
\hline Treatment $^{\mathbf{1}}$ & 56 DAS & 120 DAS \\
\hline CON & $53.3( \pm 24.4)$ & $505.0( \pm 58.4) \mathrm{d}$ \\
HERB & $12.8( \pm 13.2)$ & $46.7( \pm 39.9) \mathrm{c}$ \\
1x Gly & $13.9( \pm 28.9)$ & $16.2( \pm 14.4) \mathrm{ab}$ \\
2x Gly & $25.6( \pm 33.3)$ & $20.0( \pm 29.0) \mathrm{ab}$ \\
FST & $3.9( \pm 6.1)$ & $24.2( \pm 24.7) \mathrm{bc}$ \\
DST & $19.4( \pm 27.5)$ & $11.2( \pm 17.5) \mathrm{ab}$ \\
PL & $20.6( \pm 33.2)$ & $6.7( \pm 9.6) \mathrm{a}$ \\
DH & $10.0( \pm 11.9)$ & $22.9( \pm 23.5) \mathrm{bc}$ \\
SH & $9.4( \pm 7.3)$ & $15.4( \pm 23.6) \mathrm{ab}$ \\
\hline
\end{tabular}

${ }^{1} \mathrm{CON}=$ untreated control, HERB $=$ only cinmethylin application, $1 \mathrm{x}$ Gly $=1 \mathrm{x}$ glyphosate application, $2 x$ Gly $=2 x$ glyphosate application, FST $=$ Flat soil tillage, DST $=$ deep soil tillage, $\mathrm{PL}=$ ploughing $\mathrm{DH}=$ disc harrow, $\mathrm{SH}=$ straw harrow .

At the experimental site Risp, no significant differences in A. myosuroides density 56 DAS could be detected. Infestation rates with $A$. myosuroides of 50 plants $\mathrm{m}^{-2}$ were observed in the CON. In spring, 120 DAS, significant interaction between the stubble management strategies and the two herbicide rates were observed. On average, 302 plants m ${ }^{-2}$ were detected in the CON (Table 5).

Significant differences between the three herbicide rates were observed with increasing weed control efficacy at higher application rates. At the experimental site B. Kreuz, 56 DAS, significant interaction between the stubble management strategies and the herbicide rate could be detected. Infestation rates of 19 plants $\mathrm{m}^{-2}$ in the CON + No-till were measured. At the experimental site Sieben Jauchert, 56 DAS, no significant differences between the three application rates could be detected. On average, infestation rates with $A$. myosuroides were on a lower level, with a maximum of 7 plants $\mathrm{m}^{-2}$ in $\mathrm{CON}+\mathrm{No}$-till. In autumn, 120 DAS, infestation rates of $A$. myosuroides varied between 1 and 40 plants $\mathrm{m}^{-2}$ in the $\mathrm{CON}+$ No-till at B. Kreuz and Sieben Jauchert (Table 6).

\subsection{A. myosuroides Control Efficacy}

Within the experimental year 2019, at the experimental sites Binsen and Risp, overall high control efficacies of $80 \%$ could be achieved. Different stubble treatments followed by a pre-emergence application of cinmethylin resulted in increased, but not always significant, differences in the overall control.

At Binsen, 56 DAS, significant differences between the stubble management strategies were observed. In autumn, 100\% control efficacy was observed in the flat soil tillage treatment (FST). Within the plots of double glyphosate application (2x Gly), deep soil tillage (DST) and ploughing (PL) reduced control efficacies of $64 \%$ to $72 \%$ were detected (Figure 1A). In spring, 120 DAS, only small but significant differences between the stubble management strategies were visible. All stubble management strategies achieved $99 \%$ control efficacy, regardless of herbicide rate (Figure 1B). 
Table 5. A. myosuroides density (plants $\mathrm{m}^{-2}$ ) 56 DAS and 120 DAS at Risp. Levels of significance are shown behind the result for each date separately. Means with different small letters show significant differences within the herbicide rate of $375 \mathrm{~g}$ a.i. ha ${ }^{-1}$ according to Tukey's HSD test at $\alpha \leq 0.05$. Means with different capital letters show significant differences within the herbicide rate of $495 \mathrm{~g}$ a.i. ha ${ }^{-1}$ according to Tukey's HSD test at $\alpha \leq 0.05$.

\begin{tabular}{cccc}
\hline Treatment $^{\mathbf{1}}$ & Herbicide Rate $\left(\mathbf{g}\right.$ a.i. ha $\left.^{\mathbf{- 1}}\right)$ & $\mathbf{5 6} \mathbf{D A S}$ & $\mathbf{1 2 0} \mathbf{D A S}$ \\
\hline CON & 0 & $50( \pm 22.9)$ & $302( \pm 45.3)$ \\
\hline HERB & 375 & $0( \pm 0)$ & $9.2( \pm 9.9) \mathrm{b}$ \\
1x Gly & 375 & $1.0( \pm 3.3)$ & $4.2( \pm 5.1) \mathrm{ab}$ \\
2x Gly & 375 & $1.0( \pm 3.3)$ & $4.2( \pm 9.9) \mathrm{ab}$ \\
FST & 375 & $0( \pm 0)$ & $9.2( \pm 13.8) \mathrm{ab}$ \\
DST & 375 & $7.0( \pm 7.3)$ & $1.0( \pm 2.9) \mathrm{a}$ \\
PL & 375 & $2.2( \pm 6.7)$ & $1.0( \pm 2.9) \mathrm{a}$ \\
DH & 375 & $0( \pm 0)$ & $3.3( \pm 4.5) \mathrm{ab}$ \\
SH & 375 & $0( \pm 0) \mathrm{ab}$ \\
HERB & 495 & $0( \pm 0)$ & $0( \pm 0) \mathrm{A}$ \\
1x Gly & 495 & $1.0( \pm 3)$ & $0( \pm 0) \mathrm{A}$ \\
2x Gly & 495 & $1.0( \pm 1)$ & $0.8( \pm 0.9) \mathrm{A}$ \\
FST & 495 & $0( \pm 0) \mathrm{A}$ \\
DST & 495 & $2.2( \pm 6.7)$ & $0( \pm 0) \mathrm{A}$ \\
PL & 495 & $1.0( \pm 3.3)$ & $0( \pm 0) \mathrm{A}$ \\
DH & 495 & $0( \pm 0)$ & $0( \pm 0) \mathrm{A}$ \\
SH & 495 & $0( \pm 9) \mathrm{A}$ \\
\hline
\end{tabular}

${ }^{1} \mathrm{CON}=$ untreated control, HERB $=$ only cinmethylin application, $1 \mathrm{x}$ Gly $=1 \mathrm{x}$ glyphosate application, $2 x$ Gly $=2 x$ glyphosate application, FST $=$ Flat soil tillage, DST $=$ deep soil tillage, $\mathrm{PL}=$ ploughing, $\mathrm{DH}=$ disc harrow, $\mathrm{SH}=$ straw harrow
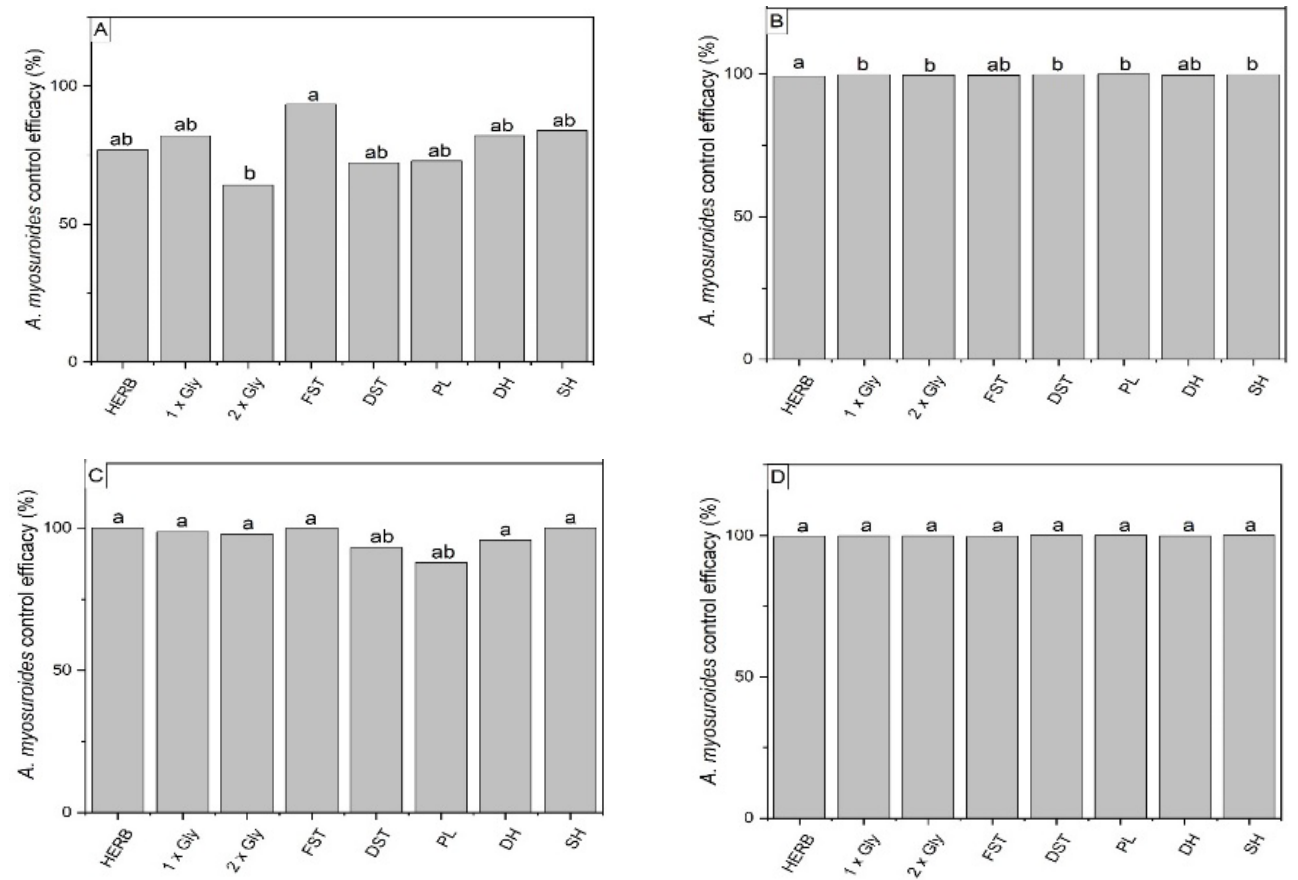

Figure 1. A. myosuroides control efficacy recorded at (A) Binsen 56 DAS, (B) Binsen 120 DAS, (C) Risp 56 DAS and (D) Risp 120 DAS from 2019 to 2020. The application rate of cinmethylin is included in the upper right corner. Means with different letters show significant differences between the treatments according to Tukey's HSD test at $\alpha \leq 0.05$. CON $=$ untreated control, HERB $=$ only cinmethylin application, 1x Gly = 1x glyphosate application, $2 x$ Gly $=2 x$ glyphosate application, FST = Flat soil tillage, $\mathrm{DST}=$ deep soil tillage, $\mathrm{PL}=$ ploughing, $\mathrm{DH}=$ disc harrow, $\mathrm{SH}=$ straw harrow. 
Table 6. A. myosuroides density (plants $\mathrm{m}^{-2}$ ) 56 DAS and 120 DAS at B. Kreuz and Sieben Jauchert. Levels of significance are shown behind the result for each experimental site and date separately. Means with different small letters show significant differences within the herbicide rate of $0 \mathrm{~g}$ a.i. ha ${ }^{-1}$ according to Tukey's HSD test at $\alpha \leq 0.05$. Means with different capital letters show significant differences within the herbicide rate of $375 \mathrm{~g}$ a.i. ha ${ }^{-1}$ according to Tukey's HSD test at $\alpha \leq 0.05$. Means with different bold small letters show significant differences within the herbicide rate of $495 \mathrm{~g}$ a.i. ha ${ }^{-1}$ according to Tukey's HSD test at $\alpha \leq 0.05$.

\begin{tabular}{|c|c|c|c|c|c|}
\hline \multirow{2}{*}{ Treatment $^{1}$} & \multirow{2}{*}{ Herbicide Rate (g a.i. ha ${ }^{-1}$ ) } & \multicolumn{2}{|c|}{56 DAS } & \multicolumn{2}{|c|}{120 DAS } \\
\hline & & B. Kreuz & Sieben Jauchert & B. Kreuz & Sieben Jauchert \\
\hline No-till + HERB & 0 & $18.8( \pm 25.2) b$ & $6.7( \pm 8.6)$ & $40( \pm 37.7)$ bcd & $68.9( \pm 51.0) b c$ \\
\hline 1x Gly & 0 & $0( \pm 0) \mathrm{a}$ & $8.9( \pm 20.3)$ & $8.9( \pm 11.3)$ a & $58.9( \pm 60.0) \mathrm{abc}$ \\
\hline 2x Gly & 0 & $2.2( \pm 4.4) \mathrm{a}$ & $4.4( \pm 5.3)$ & $15.6( \pm 20.1) \mathrm{a}$ & $92.2( \pm 83.9) \mathrm{c}$ \\
\hline FST & 0 & $2.2( \pm 4.4) \mathrm{a}$ & $2.2( \pm 4.4)$ & $45.6( \pm 43.3) \mathrm{cde}$ & $52.8( \pm 44.2) \mathrm{abc}$ \\
\hline DST & 0 & $1.4( \pm 4.0) \mathrm{a}$ & $4.3( \pm 8.9)$ & $81.1( \pm 70.5) \mathrm{e}$ & $85( \pm 74.3) b c$ \\
\hline PL & 0 & $1.1( \pm 3.3) \mathrm{a}$ & $0( \pm 0)$ & $71.7( \pm 55.8) \mathrm{de}$ & $71.7( \pm 79.9) b c$ \\
\hline $\mathrm{DH}$ & 0 & $2.2( \pm 6.7) \mathrm{a}$ & $4.4( \pm 8.8)$ & $44.4( \pm 41.9)$ cde & $31.1( \pm 32.3) \mathrm{a}$ \\
\hline $\mathrm{SH}$ & 0 & $0( \pm 0) \mathrm{a}$ & $11.1( \pm 16.9)$ & $69.4( \pm 50.2) \mathrm{de}$ & $72.8( \pm 94.4) \mathrm{abc}$ \\
\hline FSB + Gly & 0 & $1.1( \pm 3.3) \mathrm{a}$ & $2.2( \pm 4.4)$ & $26.7( \pm 23.8) \mathrm{abc}$ & $66.1( \pm 58.3) b c$ \\
\hline $\mathrm{FSB}+\mathrm{m}$ & 0 & $0( \pm 0) \mathrm{a}$ & $4.4( \pm 8.8)$ & $16.7( \pm 21.4) \mathrm{ab}$ & $56.1( \pm 62.3) \mathrm{ab}$ \\
\hline No-till + HERB & 375 & $0( \pm 0) \mathrm{A}$ & $0( \pm 0)$ & $1.1( \pm 3.2) \mathrm{A}$ & $0.6( \pm 2.4) \mathrm{A}$ \\
\hline 1x Gly & 375 & $0( \pm 0) \mathrm{A}$ & $0( \pm 0)$ & $2.2( \pm 4.2) \mathrm{A}$ & $2.2( \pm 7.3) \mathrm{A}$ \\
\hline 2x Gly & 375 & $1.1( \pm 3.3) \mathrm{A}$ & $0( \pm 0)$ & $1.7( \pm 5.1) \mathrm{A}$ & $1.7( \pm 5.1) \mathrm{A}$ \\
\hline FST & 375 & $4.4( \pm 7.3) \mathrm{A}$ & $0( \pm 0)$ & $2.8( \pm 7.5) \mathrm{A}$ & $0.6( \pm 2.4) \mathrm{A}$ \\
\hline DST & 375 & $0( \pm 0) \mathrm{A}$ & $0( \pm 0)$ & $13.3( \pm 28.5) \mathrm{A}$ & $1.7( \pm 74.3) \mathrm{A}$ \\
\hline PL & 375 & $4.4( \pm 8.8) \mathrm{A}$ & $0( \pm 0)$ & $8.3( \pm 18.6) \mathrm{A}$ & $5.6( \pm 14.6) \mathrm{A}$ \\
\hline $\mathrm{DH}$ & 375 & $0( \pm 0) \mathrm{A}$ & $0( \pm 0)$ & $3.9( \pm 12.0) \mathrm{A}$ & $1.1( \pm 3.2) \mathrm{A}$ \\
\hline $\mathrm{SH}$ & 375 & $2.2( \pm 6.7) \mathrm{A}$ & $0( \pm 0)$ & $2.8( \pm 5.8) \mathrm{A}$ & $2.8( \pm 5.7) \mathrm{A}$ \\
\hline FSB + Gly & 375 & $0( \pm 0) \mathrm{A}$ & $0( \pm 0)$ & $3.3( \pm 8.4) \mathrm{A}$ & $3.9( \pm 12.4) \mathrm{A}$ \\
\hline $\mathrm{FSB}+\mathrm{m}$ & 375 & $1.1( \pm 3.3) \mathrm{A}$ & $0( \pm 0)$ & $13.9( \pm 45.5) \mathrm{A}$ & $1.1( \pm 3.2) \mathrm{A}$ \\
\hline No-till + HERB & 495 & $0( \pm 0) \mathbf{a}$ & $0( \pm 0)$ & $3.3( \pm 9.7) \mathbf{a}$ & $3.5( \pm 12.2) \mathbf{a}$ \\
\hline 1x Gly & 495 & $1.1( \pm 3.3) \mathbf{a}$ & $0( \pm 0)$ & $3.9( \pm 12.4) \mathbf{a}$ & $5( \pm 16.5) \mathbf{a}$ \\
\hline 2x Gly & 495 & $0( \pm 0) \mathbf{a}$ & $0( \pm 0)$ & $0( \pm 0) \mathbf{a}$ & $1.7( \pm 3.8) \mathbf{a}$ \\
\hline FST & 495 & $0( \pm 0) \mathbf{a}$ & $0( \pm 0)$ & $9.4( \pm 17.3)$ a & $0( \pm 0) \mathbf{a}$ \\
\hline DST & 495 & $1( \pm 4.0) \mathbf{a}$ & $0( \pm 0)$ & $3.9( \pm 28.5)$ a & $1.1( \pm 3.23) \mathrm{a}$ \\
\hline PL & 495 & $1.1( \pm 3.3) \mathbf{a}$ & $0( \pm 0)$ & $8.9( \pm 20.5)$ a & $0( \pm 0) \mathbf{a}$ \\
\hline $\mathrm{DH}$ & 495 & $0( \pm 0) \mathbf{a}$ & $0( \pm 0)$ & $1.7( \pm 3.8) \mathbf{a}$ & $0.5( \pm 2.4) \mathbf{a}$ \\
\hline $\mathrm{SH}$ & 495 & $0( \pm 0) \mathbf{a}$ & $0( \pm 0)$ & $1.1( \pm 3.2) \mathbf{a}$ & $0( \pm 0) \mathbf{a}$ \\
\hline FSB + Gly & 495 & $0( \pm 0) \mathbf{a}$ & $0( \pm 0)$ & $2.7( \pm 7.5) \mathbf{a}$ & $0( \pm 0) \mathbf{a}$ \\
\hline $\mathrm{FSB}+\mathrm{m}$ & 495 & $0( \pm 0) \mathbf{a}$ & $0( \pm 0)$ & $0.5( \pm 2.4) \mathbf{a}$ & $2.7( \pm 6.7) \mathbf{a}$ \\
\hline
\end{tabular}

${ }^{1}$. No-till + HERB $=$ No soil tillage with chemical weed management, $1 x$ Gly $=1 \mathrm{x}$ glyphosate application, $2 x$ Gly $=2 x$ glyphosate application, FST $=$ Flat soil tillage, $\mathrm{DST}=$ deep soil tillage, $\mathrm{PL}=$ ploughing, $\mathrm{DH}=$ disc harrow, $\mathrm{SH}=$ straw harrow, $\mathrm{FSB}+\mathrm{Gly}=$ false seedbed + glyphosate, $\mathrm{FSB}+\mathrm{m}=$ false seedbed + rotary hoe.

At the experimental site Risp, 56 DAS, significant differences were observed between the stubble management strategies. In autumn, the FST treatment reduced $A$. myosuroides density by $100 \%$. Reduced control efficacies of $93 \%$ and $87 \%$ were observed in the treatments of DST and PL, respectively (Figure 1C). In spring, 120 DAS, no significant differences could be observed. Similarly, at this experimental site, all stubble management strategies were able to achieve a control efficacy of 99\% 120 DAS (Figure 1D).

At the experimental site B. Kreuz, 56 DAS, significant interaction between herbicide rate and stubble management strategy were observed. The highest control efficacy of over $94 \%$ was achieved by all stubble management strategies in combination with a cinmethylin rate of $495 \mathrm{~g}$ a.i.. The $A$. myosuroides control efficacy decreased at cinmethylin rate $375 \mathrm{~g}$ a.i. and $0 \mathrm{~g}$ a.i., respectively. All stubble management strategies within the application dose of $375 \mathrm{~g}$ a.i. achieved control efficacies of over $89 \%$ with the exception of FST (72\%) and PL (79\%). The stubble management strategies without herbicide application achieved control 
efficacies of over $89 \%$ with the exception of FST and 1x glyphosate (1x Gly), which showed a reduced efficacy of $83 \%$ (Figure $2 \mathrm{~A}$ ).
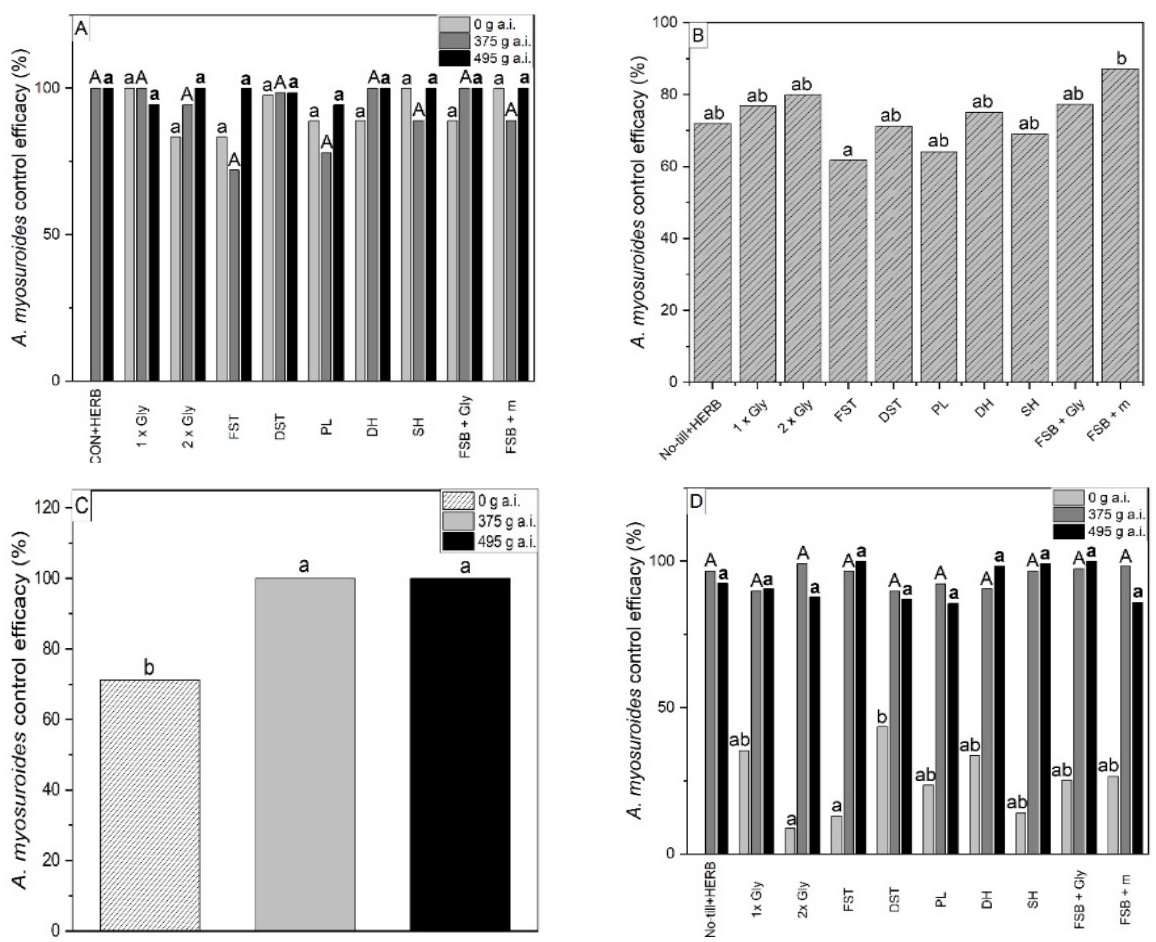

Figure 2. A. myosuroides control efficacy recorded at (A) B. Kreuz 56 DAS, (B) B. Kreuz 120 DAS, (C) Sieben Jauchert 56 DAS and (D) Risp 120 DAS from 2019 to 2020. The application rate of cinmethylin is included in the upper right corner. Means with different letters show significant differences between the treatments according to Tukey's HSD test at $\alpha \leq 0.05$. No-till + HERB $=$ No soil tillage with chemical weed management, $1 \times$ Gly $=1 x$ glyphosate application, $2 x$ Gly $=2 x$ glyphosate application, FST = Flat soil tillage, DST = deep soil tillage, $\mathrm{PL}=$ ploughing, $\mathrm{DH}=$ disc harrow, $\mathrm{SH}=$ straw harrow, FSB + Gly $=$ false seedbed + glyphosate, FSB $+\mathrm{m}=$ false seedbed + rotary hoe.

In spring, 120 DAS, no significant differences between the herbicide rates could be detected. The highest control efficacy of $87 \%$ was achieved by the treatment of false seedbed preparation followed by a rotary hoe $(\mathrm{FSB}+\mathrm{m})$. The poorest effect was observed for the stubble management strategy FST with 62\% efficacy (Figure 2B).

At the second experimental site Sieben Jauchert in 2020, significant differences between the herbicide rates were detected. On average, across all stubble management strategies that had not been treated with cinmethylin, a 30\% reduction in control efficacy was observed compared to the $375 \mathrm{~g}$ a.i. and $495 \mathrm{~g}$ a.i. rates $56 \mathrm{DAS}$ (Figure 2C).

In the subsequent year, 120 DAS, a significant interaction between the herbicide rate and the stubble management strategy was detected. At this experimental site, big differences were visible between the cinmethylin-treated plots and the untreated plots. Within the cinmethylin rate of $495 \mathrm{~g}$ a.i., control efficacies of over $87 \%$ were observed. The highest control efficacy of $100 \%$ was detected within the false seedbed preparation followed by a glyphosate application (FSB + Gly) and DST. A reduced control efficacy of $85 \%$ was observed by PL and FSB $+m$. As at the experimental site B. Kreuz, all stubble management strategies in combination with $375 \mathrm{~g}$ a.i. achieved a control efficacy of minimum $89 \%$. The highest control efficacy of $99 \%$ was achieved by double glyphosate application (2x Gly) and FSB+m. Control efficacy of the stubble management strategies without cinmethylin treatment was less than $50 \%$. The $2 x$ Gly treatment, with less than $10 \%$ efficacy, performed worst while the DST treatment, with almost 43\% efficacy, performed best (Figure 2D). 


\subsection{Winter Wheat Densities in the Field Experiments}

Pre-emergence herbicide application with cinmethylin had no phytotoxic effect on winter wheat density. Therefore, all dose rates of cinmethylin tested at the different locations were pooled for the individual stubble treatments. The density of winter wheat was above 200 plants $\mathrm{m}^{-2}$ in all treatments except for the CON at the sites Binsen and Risp (Table 7), where significantly lower densities ranging from 138 to 142 plants $\mathrm{m}^{-2}$ were counted. The highest densities of winter wheat plants were observed in PL plots with 288 and 281 plants $\mathrm{m}^{-2}$ at the sites Binsen and Risp. For B. Kreuz and Sieben Jauchert, the highest densities were observed with the 2x Gly application with 265 and 295 plants $\mathrm{m}^{-2}$.

Table 7. Winter wheat density (plants $\mathrm{m}^{-2}$ ) 120 DAS (Binsen, Risp, B. Kreuz and Sieben Jauchert). Levels of significance are shown behind the result for each experimental site separately. Means with the same letter are not significantly different according to HSD test at $p \leq 0.05$. Levels of significance are shown behind the result for each experimental site separately.

\begin{tabular}{ccccc}
\hline Treatments $^{\mathbf{1}}$ & Binsen & Risp & B. Kreuz & Sieben Jauchert \\
\hline CON & $138 \mathrm{a}$ & $142 \mathrm{a}$ & - & - \\
HERB & $209 \mathrm{~b}$ & $220 \mathrm{~b}$ & - & - \\
No-till + HERB & - & - & $258 \mathrm{a}$ & $286 \mathrm{a}$ \\
1x Gly & $254 \mathrm{~cd}$ & $258 \mathrm{bc}$ & $244 \mathrm{a}$ & $290 \mathrm{a}$ \\
$2 \mathrm{x}$ Gly & $276 \mathrm{~cd}$ & $286 \mathrm{c}$ & $265 \mathrm{a}$ & $295 \mathrm{a}$ \\
FST & $270 \mathrm{~cd}$ & $248 \mathrm{bc}$ & $256 \mathrm{a}$ & $282 \mathrm{a}$ \\
DST & $281 \mathrm{~cd}$ & $269 \mathrm{bc}$ & $255 \mathrm{a}$ & $280 \mathrm{a}$ \\
PL & $288 \mathrm{~d}$ & $276 \mathrm{bc}$ & $249 \mathrm{a}$ & $289 \mathrm{a}$ \\
DH & $236 \mathrm{bc}$ & $281 \mathrm{c}$ & $249 \mathrm{a}$ & $292 \mathrm{a}$ \\
SH & $242 \mathrm{bcd}$ & $220 \mathrm{~b}$ & $249 \mathrm{a}$ & $286 \mathrm{a}$ \\
FSB + Gly & - & - & $258 \mathrm{a}$ & $298 \mathrm{a}$ \\
FSB + m & - & - & $264 \mathrm{a}$ & $280 \mathrm{a}$ \\
\hline
\end{tabular}

${ }^{1} \mathrm{CON}=$ untreated control, HERB $=$ only cinmethylin application, No-till + HERB $=$ No soil tillage with chemical weed management, $1 \times$ Gly $=1 x$ glyphosate application, $2 x$ Gly $=2 x$ glyphosate application, FST = Flat soil tillage, $\mathrm{DST}=$ deep soil tillage, $\mathrm{PL}=$ ploughing, $\mathrm{DH}=$ disc harrow, $\mathrm{SH}=$ straw harrow, FSB + Gly = false seedbed + glyphosate, $\mathrm{FSB}+\mathrm{m}=$ false seedbed + rotary hoe.

\subsection{Winter Wheat Grain Yield}

According to the statistical analysis, no significant interaction between the application rates of cinmethylin and the stubble management strategies could be detected in regard to the grain yield. At the site B. Kreuz, grain yield could not significantly increase due to stubble treatments compared to the untreated control. Between the stubble treatments at the site Sieben Jauchert, no significant differences between the application rates of cinmethylin and the stubble treatments could be observed (Table 8).

Table 8. Winter wheat grain yield $\left(\mathrm{Mg} \mathrm{ha}^{-1}\right)$ in 2020 at B. Kreuz and Sieben Jauchert. Levels of significance are shown behind the result for each experiment site separately. Means with the same letter are not significantly different according to HSD test at $p \leq 0.05$. Levels of significance are shown behind the result for each experiment site separately.

\begin{tabular}{ccc}
\hline Treatments $^{1}$ & B. Kreuz & Sieben Jauchert \\
\hline No-till + HERB & $7.7 \mathrm{c}$ & $8.4 \mathrm{a}$ \\
1x Gly & $7.5 \mathrm{bc}$ & $8.5 \mathrm{a}$ \\
2x Gly & $7.5 \mathrm{bc}$ & $8.6 \mathrm{a}$ \\
FST & $7.5 \mathrm{bc}$ & $8.4 \mathrm{a}$ \\
DST & $7.1 \mathrm{abc}$ & $8.6 \mathrm{a}$ \\
PL & $6.3 \mathrm{a}$ & $8.5 \mathrm{a}$ \\
DH & $6.8 \mathrm{abc}$ & $8.8 \mathrm{a}$ \\
SH & $6.5 \mathrm{ab}$ & $8.8 \mathrm{a}$ \\
FSB + Gly & $7.1 \mathrm{abc}$ & $8.7 \mathrm{a}$ \\
\hline
\end{tabular}

${ }^{1}$ No-till + HERB $=$ No soil tillage with chemical weed management, 1x Gly $=1 x$ glyphosate application $2 \mathrm{x}$ Gly $=2 \mathrm{x}$ glyphosate application, FST $=$ Flat soil tillage, $\mathrm{DST}=$ deep soil tillage, $\mathrm{PL}=$ ploughing, $\mathrm{DH}=$ disc harrow, $\mathrm{SH}=$ straw harrow, $\mathrm{FSB}+\mathrm{Gly}=$ false seedbed + glyphosate, $\mathrm{FSB}+\mathrm{m}=$ false seedbed + rotary hoe. 


\section{Discussion}

Both application rates of cinmethylin, 375 and $495 \mathrm{~g}$ a.i. ha ${ }^{-1}$, could reduce $A$. myosuroides density by 86 to $97 \%$ and 95 to $100 \%$, respectively. Therefore, Hypothesis (i) was proved in this study. High efficacy (98\%) of $495 \mathrm{~g}$ a.i. ha $^{-1}$ cinmethylin against $A$. myosuroides was also found in previous field studies [27]. A lower rate of $375 \mathrm{~g}$ a.i. ha ${ }^{-1}$ cinmethylin still provided $80 \%$ control efficacy against $A$. myosuroides, which corresponded well to the $85 \%$ weed control efficacy against Lolium rigidum L. in Australian field studies [28]. Those ryegrass populations in Australia already showed high levels of resistance against trifluralin, indicating that cinmethylin is not affected by resistance to other herbicide modes of action.

Control efficacy of cinmethylin against $A$. myosuroides was similar to other pre-emergence herbicides commonly used in Western European winter wheat fields. In the studies of Bailly et al. [14], the combination of flufenacet and pendimethalin and also the single application of flufenacet controlled $95-97 \%$ and $98 \%$, respectively. Flufenacet efficacy against $A$. myosuroides was slightly reduced to $75 \%$ in a previous study [27]. However, weed control efficacies of pre-emergence herbicides may differ from year to year because of variations in soil water content, limited soil persistence and a long germination period of A. myosuroides from autumn to spring [29]. Furthermore, pre-emergence herbicides can be lost due to surface evaporation or leaching in wet soils [29,30]. Sufficient soil moisture, temperature and the very early developmental stages of the weeds at the time of herbicide application are necessary for high efficacies of pre-emergence herbicide use [29,30]. In addition, factors such as herbicide dose, persistence, spraying accuracy, seedbed conditions and weed emergence patterns also influence the efficacy of a pre-emergence herbicide [31]. Reduced control efficacies of pre-emergence herbicides were often observed under dry conditions and at high clay and organic matter contents [29,32,33]. Dry conditions, such as those experienced in the autumn of 2018, showed greater variation in the potential to create a fine and firm seedbed following the different stubble treatments. The persistence of pre-emergence herbicides in the soil is often insufficient to provide effective weed control until BBCH 30 of winter cereals [29].

Nevertheless, in the present study, the reduced rate of $375 \mathrm{~g}$ a.i. cinmethylin achieved similar control efficacies to that of the full rate of $495 \mathrm{~g}$ a.i. cinmethylin. Thus, Hypothesis (ii) was also proved. Within both experimental years, A. myosuroides control efficacies of minimum $89 \%$ were achieved by the reduced cinmethylin rate in winter wheat without any stubble treatment. In addition, other studies reported that a $50 \%$ dose of tralkoxydim consistently gave over $85 \%$ control of wild oat (Avena fatua L.) in barley (Hordeum vulgare L.) [34]. An Australian study by Walker et al. [35] found that the efficacy of clodinafop and tralkoxydim on wild oat (Avena ludoviciana Durieu.) and paradoxa grass (Phalaris paradoxa L.) was still adequate at 50 to $75 \%$ of the recommended doses. Nevertheless, reduced herbicide rates carry a high risk of inadequate weed control. Reduced herbicide rates might quicken the process of resistance development. In previous years, the use of reduced rates of herbicides has been associated with the increasing number of cases of non-target site resistance in grass species such as A. myosuroides and Lolium ssp [36]. In cases where the least susceptible individuals in the population survive the use of reduced rates, this selection leads to a stepwise increase in the resistance level in the weed population. This is valid if the use of reduced herbicide rates is due to lower efficacy, but not if high susceptibility of weed species present in the field or optimal conditions are the reasons for reducing herbicide rates [36]. A high abundance in weed population increases the risk of selecting resistant weed biotypes because the probability of having resistant plants in the population increases with population size. One of the main purposes of integrated weed management (IWM) is to suppress problematic weed species using multiple tactics of weed control [36,37]. IWM is also implemented in the Green Deal targets and Farm-to-Fork (F2F) strategy, which was published in May 2020. The F2F aims to make the EU food system fair, healthy and environmentally friendly and was established as a cornerstone of the European Green Deal under the European Commission's program for the period 2019 to 2024. The 
Commission calls for a reduction of the overall use and risk of chemical pesticides by $50 \%$. Combining the use of herbicides with other weed control methods (e.g., tillage, cover crops, crop rotation, competitive crops, high crop seed rates, reduced row spacing and specific fertilizer placement) reduces the risk of resistance development [38-41].

Preventive and cultural control measures before sowing the main crop are elements of IWM, which shall reduce the plant density of $A$. myosuroides in the following crop, thereby supporting the control level of the subsequent herbicide application within the crop [37]. Stubble soil cultivation and/or glyphosate application, as used in this study, varied in their effects and supporting contributions to the control efficacy of cinmethylin. Most effective and consistent was the use of glyphosate (over 77\%) and disc harrow (DH), with control efficacies over $76 \%$ by $\mathrm{BBCH} 30$ of the winter wheat. In the first experimental year, the FST treatment showed control efficacies of over $93 \%$ in spring. In the second experimental year, both FSB treatments reached control efficacies of $77-100 \%$. Therefore, Hypothesis (iii), that pre-emergence application of cinmethylin in combination with a mechanical stubble treatment achieves similar control efficacy of $A$. myosuroides as a sequence with a pre-sowing glyphosate treatment in winter wheat, was also proved in this study. However, shallow tillage can be very effective against annual weeds because even A. myosuroides seeds with no or short dormancy are stimulated to germinate shortly after tillage. Seedlings that have already germinated could then be removed before sowing winter cereals [42] The efficiency of the different strategies could be increased by applying the pre-emergence herbicide. The high control efficacy of the FSB treatments agrees with a study by Menegat and Nilsson [6], where the combination of false seedbed preparation with an herbicide treatment in autumn achieved control efficacies of up to $85 \%$. Nevertheless, the control efficacy of a pre-sowing glyphosate treatment is high, as expected. In contrast to findings of Schappert et al. [21], the 1x Gly also achieved high control efficacies of up to $100 \%$. However, the use of glyphosate has recently been under strong criticism, and its future use in the EU after expiration of approval in December 2022 is open. Therefore, it is becoming increasingly important to investigate how cultural weed control measures are able to at least partially replace autumn to spring glyphosate applications. Tendencies that were already visible in autumn became evident in spring. Further, this indicates a long-lasting persistence of the new pre-emergence herbicide.

In this study, cinmethylin did not damage winter wheat crops. Winter wheat densities were higher in the cinmethylin treatments compared to the untreated controls. Furthermore, winter wheat grain yield did not reduce due to a cinmethylin application. Thus, Hypothesis (iv) was also confirmed. Within all four experiments, crop seeds were placed at a depth of $3 \mathrm{~cm}$. In an Australian study, a high degree of selectivity of cinmethylin was also observed, where wheat seeds were placed at a depth of $1 \mathrm{~cm}$ [28]. As a result, no differences in seedling emergence were observed between the cinmethylin-treated and untreated control plots [28]. In a study of Messelhäuser et al. [27], it was also demonstrated that the application of pre-emergence herbicides, especially cinmethylin, does not reduce winter wheat grain yields. However, it also did not lead to a constant increase in winter wheat grain yield. According to this study, it has to be mentioned that crop damage due to the application of cinmethylin could occur if crop seeds are in direct contact with the herbicide. Conversely, this also increases the weed control effect. Selectivity and efficacy of cinmethylin will depend on the relative position of the crop and weed seeds, seedbed quality and absorption potential on clay minerals and soil organic matter.

\section{Conclusions}

In a two-year study on four experimental sites in Southwest Germany, it was demonstrated that cinmethylin at both application rates provides control efficacies of more than $94 \%$ against $A$. myosuroides until $\mathrm{BBCH} 30$ in winter wheat. Furthermore, the combination of $375 \mathrm{~g}$ a.i. cinmethylin with different stubble management strategies achieves similar control efficacies as the application of $495 \mathrm{~g}$ a.i. cinmethylin. Stubble tillage practices and stubble applications of glyphosate resulted in additional weed control efficacy to the cinmethylin 
treatments. In addition to high efficacy in weed control, cinmethylin also provided good selectivity to winter wheat.

Already announced by the National Research Council [43] "The destruction of weeds by chemicals must of course be supplementary to crop rotation, summer fallowing and other control methods, which will always have a prominent place". In order to reduce herbicide use in agriculture while still maintaining high yields and adequate weed control, a diverse weed control strategy is required. IWM measures imply increased system complexity, which may make their adoption by farmers difficult. Nevertheless, the results show that cinmethylin can successfully be used for the control of $A$. myosuroides in combination with different stubble tillage methods and/or glyphosate application, making it a valuable tool in integrated weed and resistance management strategies with its novel and unique mode of action.

Author Contributions: M.H.M. was responsible for the experiments, did the statistical analysis and wrote the manuscript. M.S. was responsible for the experiments and revised the manuscript. B.S. revised the manuscript. R.G. supervised the experiments and revised the manuscript. All authors have read and agreed to the published version of the manuscript.

Funding: This research received external funding of BASF SE.

Conflicts of Interest: Author B.S. is an employee of BASF. He was involved in the development of cinmethylin. B.S. had no role in the design of the study; in the collection, analyses, or interpretation of data; in the writing of the manuscript or in the decision to publish the results.

\section{References}

1. Lutman, P.J.W.; Moss, S.R.; Cook, S.; Welham, S.J. A review of the effects of crop agronomy on the management of Alopecurus myosuroides. Weed Res. 2013, 53, 299-313. [CrossRef]

2. Chauvel, B.; Guillemin, J.-P.; Colbach, N. Evolution of a herbicide-resistant population of Alopecurus myosuroides Huds. in a long-term cropping system experiment. Crop Prot. 2009, 28, 343-349. [CrossRef]

3. Rüegg, W.T.; Quadranti, M.; Zoschke, A. Herbicide research and development: Chal-lenges and opportunities. Weed Res. 2007, 47, 271-275. [CrossRef]

4. Moss, S.R.; Perryman, S.A.; Tatnell, L.V. Managing Herbicide-resistant Blackgrass (Alopecurus myosuroides): Theory and Practice. Weed Technol. 2007, 21, 300-309. [CrossRef]

5. Chauvel, B.; Guillemin, J.; Colbach, N.; Gasquez, J. Evaluation of cropping systems for management of herbicide-resistant populations of blackgrass (Alopecurus myosuroides Huds.). Crop Prot. 2001, 20, 127-137. [CrossRef]

6. Menegat, A.; Nilsson, A.T.S. Interaction of Preventive, Cultural, and Direct Methods for Integrated Weed Management in Winter Wheat. Agronomy 2019, 9, 564. [CrossRef]

7. Délye, C.; Jasieniuk, M.; Le Corre, V. Deciphering the evolution of herbicide resistance in weeds. Trends Genet. 2013, 29, 649-658. [CrossRef] [PubMed]

8. Heap, I. Global perspective of herbicide-resistant weeds. Pest Manag. Sci. 2014, 70, 1306-1315. [CrossRef]

9. Moss, S. Black-grass (Alopecurus myosuroides): Why has this Weed become such a Problem in Western Europe and what are the Solutions? Outlooks Pest Manag. 2017, 28, 207-212. [CrossRef]

10. Moss, S.R. The survival of Alopecurus myosuroides Huds. seeds in soil. Weed Res. 1985, 25, 201-211. [CrossRef]

11. Gerhards, R.; Dentler, J.; Gutjahr, C.; Auburger, S.; Bahrs, E. An approach to investigate the costs of herbicide-resistant Alopecurus myosuroides. Weed Res. 2016, 56, 407-414. [CrossRef]

12. Zeller, A.; Kaiser, Y.; Gerhards, R. Suppressing Alopecurus myosuroides Huds. in Rota-tions of Winter-Annual and Spring Crops. Agriculture 2018, 8, 91. [CrossRef]

13. Menne, H.J.; Hogrefe, C. Impact of multiple resistance mechanisms in black-grass (Alopecurus myosuroides Huds.) populations on the of cereal herbicides. Julius-Kühn-Archiv 2012, 434, 65-74. [CrossRef]

14. Bailly, G.C.; Dale, R.P.; Archer, S.A.; Wright, D.J.; Kaundun, S.S. Role of residual herbi-cides for the management of multiple herbicide resistance to ACCase and ALS inhibi-tors in a black-grass population. Crop Prot. 2012, 34, 96-103. [CrossRef]

15. Dücker, R.; Zöllner, P.; Parcharidou, E.; Ries, S.; Lorentz, L.; Beffa, R. Enhanced metabo-lism causes reduced flufenacet sensitivity in black-grass (Alopecurus myosuroides Huds.) field populations. Pest Manag. Sci. 2019, 75, 2996-3004. [CrossRef]

16. Klingenhagen, G. Comparison of different black-grass populations (Alopecurus myosuroides Huds.) in their susceptibility to herbicides under field conditions. Julius-Kühn-Archiv 2012, 434, 81-87. [CrossRef]

17. Campe, R.; Hollenbach, E.; Kämmerer, L.; Hendriks, J.; Höffken, H.W.; Kraus, H.; Ler-chl, J.; Mietzner, T.; Tresch, S.; Witschel, M.; et al. A new herbicidal site of action: Cinmethylin binds to acyl-ACP thioesterase and inhibits plant fatty acid biosynthesis. Pestic. Biochem. Physiol. 2018, 148, 116-125. [CrossRef]

18. Dayan, F.E. Current Status and Future Prospects in Herbicide Discovery. Plants 2003, 8, 341. [CrossRef] [PubMed] 
19. Messelhäuser, M.H.; Linn, A.I.; Mathes, A.; Sievernich, B.; Gerhards, R. Development of an Agar Bioassay Sensitivity Test in Alopecurus myosuroides for the Pre-Emergence Herbicides Cinmethylin and Flufenacet. Agronomy 2021, 11, 1408. [CrossRef]

20. Moss, S.R. (Ed.) The Seed Cycle of Alopecurus Myosuroides in Winter Cereals: A Quantitative Analysis; European Weed Research Society: Helsinki, Finland, 1990.

21. Schappert, A.; Messelhäuser, M.; Saile, M.; Peteinatos, G.; Gerhards, R. Weed Suppres-sive Ability of Cover Crop Mixtures Compared to Repeated Stubble Tillage and Glyphosate Treatments. Agriculture 2018, 8, 144. [CrossRef]

22. Pekrun, C.; Claupein, W. The implication of stubble tillage for weed population dy-namics in organic farming. Weed Res. 2006, 46, 414-423. [CrossRef]

23. Moss, S.R. A study of populations of black-grass (Alopecurus myosuroides) in winter wheat, as influenced by seed shed in the previous crop, cultivation system and straw disposal method. Ann. Appl. Biol. 1980, 94, 121-126. [CrossRef]

24. Melander, R. Reducing intrarow weed numbers in row crops by means of a biennial cultivation system. Weed Res. 2000, 40 , 205-218. [CrossRef]

25. Bond, W.; Grundy, A.C. Non-chemical weed management in organic farming systems. Weed Res. 2001, 41, 383-405. [CrossRef]

26. Agrarmeteorologie Baden-Württemberg. Wetterstation Unterjesingen. Available online: https://www.wetter-bw.de/Internet/ AM/NotesBwAM.nsf/bwweb/4262596897754529c1257ca8002f9d19?OpenDocument\&TableRow=3.1.2,3.5\#3.1. (accessed on 10 December 2021).

27. Messelhäuser, M.; Saile, M.; Sievernich, B.; Gerhards, R. Effect of cinmethylin against Alopecurus myosuroides Huds. in winter cereals. Plant Soil Environ. 2021, 67, 46-54. [CrossRef]

28. Busi, R.; Dayan, F.E.; Francis, I.; Goggin, D.; Lerchl, J.; Porri, A.; Powles, S.B.; Sun, C.; Beckie, H.J. Cinmethylin controls multiple herbicide-resistant Lolium rigidum and its wheat selectivity is P450-based. Pest Manag. Sci. 2020, 76, 2601-2608. [CrossRef] [PubMed]

29. Kudsk, P.; Kristensen, J.L. (Eds.) Effect of Environmental Factors on Herbicide Performance; Weed Science Society of Victoria: Victoria, Australia, 1992.

30. Hammerton, J.L. Environmental Factors and Susceptibility to Herbicides. Weeds 1967, 15, 330-336. [CrossRef]

31. Menne, H.J.; Laber, B.; Kerlen, D.; Beffa, R. Effectiveness of flufenacet in controlling re-sistant black-grass (Alopecurus myosuroides Huds.)-Comparison of glasshouse and field trial results. Julius-Kühn-Archiv 2012, 434, 401-408. [CrossRef]

32. Akesson, N.B.; Yates, W.E. Effect of Weather Factors on the Application of Herbicides. In Methods of Applying Herbicides; McWhorter, C.G., Gebhardt, M.R., Eds.; Weed Science Society of America: Champaign, IL, USA, 1987; pp. 335-344.

33. Medd, R.W.; van de Ven, R.J.; Pickering, D.I.; Nordblom, T. Determination of environ-ment-specific dose-response relationships for clodinafop-propargyl on Avena spp. Weed Res. 2001, 41, 351-368. [CrossRef]

34. Belles, D.S.; Thill, D.C.; Shafii, B. PP-604 rate and Avena fatua density effects on seed production and viability in Hordeum vulgare. Weed Sci. 2000, 48, 378-384. [CrossRef]

35. Walker, S.R.; Medd, R.W.; Robinson, G.R.; Cullis, B.R. Improved management of Avena ludoviciana and Phalaris paradoxa with more densely sown wheat and less herbicide. Weed Res. 2002, 42, 257-270. [CrossRef]

36. Kudsk, P. Reduced herbicide rates: Present and future. Julius-Kühn-Archiv 2014, 443, 37-44.

37. Harker, K.N.; O’Donovan, J.T. Recent Weed Control, Weed Management, and Inte-grated Weed Management. Weed Technol. 2013, 27, 1-11. [CrossRef]

38. Lemerle, D.; Gill, G.S.; Murphy, C.E.; Walker, S.R.; Cousens, R.D.; Mokhtari, S.; Peltzer, S.J.; Coleman, R.; Luckett, D.J. Genetic improvement and agronomy for enhanced wheat competitiveness with weeds. Aust. J. Agric. Res. 2001, 52, 527-548. [CrossRef]

39. Sarrantonio, M.; Gallandt, E. The Role of Cover Crops in North American Cropping Systems. J. Crop Prod. 2003, 8, 53-74. [CrossRef]

40. Blackshaw, R.E.; Molnar, L.J.; Janzen, H.H. Nitrogen fertilizer timing and application method affect weed growth and competition with spring wheat. Weed Sci. 2004, 52, 614-622. [CrossRef]

41. Zhang, J.; Weaver, S.E.; Hamill, A.S. Risks and reliability of using herbicides at be-low-labeled rates. Weed Technol. 2000, 14, 106-115. [CrossRef]

42. Moss, S.R.; Clarke, J.H. Guidelines for the prevention and control of herbicide-resistant black-grass (Alopecurus myosuroides Huds.). Crop Prot. 1994, 13, 230-234. [CrossRef]

43. National Research Council. Proceedings of a Conference on the Destruction of Weeds by Means of Chemicals; National Research Council: Edmonton, AB, Canada, 1929; 168p. 